\title{
Monitoring of Litigation Costs and Efforts to Eradicate Judicial Corruption Practices
}

\author{
Zaka Firma Aditya ${ }^{1}$, Sholahuddin Al-Fatih ${ }^{2}$ \\ ${ }^{1}$ Center for Research and Case Analysis, Constitutional Court of \\ Republic of Indonesia, Jakarta, Indonesia \\ ${ }^{2}$ Faculty of Law, Universitas Muhammadiyah Malang, Indonesia \\ Corresponding Author: Z.F. Aditya, email: zaka.firma@mkri.id
}

\begin{abstract}
Judicial corruption practices in Indonesia have been going on for long time. Even, according to the Transparency International survey (2007), the judiciary in Indonesia ranks the highest for corruption perception index. Not only that, the mode used by the judicial mafia is also increasingly modern and occurs almost in all aspects of judiciary. This research has two aims, namely: (1) to know and analyze the mode of corruption in the judicial process in Indonesia, and (2) to know and analyze the model of litigation cost control in the judicial process in Indonesia. This research is a juricial-normative research which is using the statute approach and conceptual approach. From this research, it can be seen that, typically, corrupt practices have been initiated since the registration of the case, the establishment of the judges panel, summoning witnesses and experts, negotiating decisions and costs of copy of the decisions. Ironically, many parties are involved in the judicial corruption practices ranging from clerks, officials and employers in the judiciary and the judges themselves. However, the more modern technology can be used as an alternative solution in combating the practices of judicial corruption. One of them, by applying litigation cost control that can be integrated through a whistleblowing system. In this way, the public can monitor in real-time the trial process starting from registration litigation fees, the process of litigation until post-verification, officials and employers in the judiciary and the judges themselves.
\end{abstract}

Keywords: Corruption; Judicial Process; Controlling; Litigation Costs; Whistleblowing

How to cite:

Aditya, Z. F., \& Al-Fatih, S. (2020). Monitoring of Litigation Costs and Efforts to Eradicate Judicial Corruption Practices. Indonesian Journal of Advocacy and Legal Services, 2(2), 261276. https://doi.org/10.15294/ijals.v2i2.38148 


\section{A. Introduction}

The working procedure of judicial power in Indonesia has long been highlighted and discussed both by the community and by legal experts. This is due to the existence of the values of community justice that continue to be shackled by the many practices of justice and justice that have lasted a long time. Yet if you look at its philosophy, an old Latin proverb illustrates how glorious a judicial institution. The court was seen as a "nec curia deficit in justitia exhibenda" (the court is a palace where the goddess of justice resides to give out a never-ending scent of justice). ${ }^{1}$ This proverb actually tries to reflect the existence of the world of justice which is actually very very noble, authoritative and where the principles of justice are housed. ${ }^{2}$ Moreover, the judges when trying and deciding cases must incarnate themselves and act as "God's representatives" on earth. In fact, in making decisions, the judges are stuck on the divine values as in the ruling, the verdict always writes the phrase "For the sake of justice based on Godhead". This moral burden is very heavy because the responsibility is not only horizontally to fellow human beings, but also vertical responsibilities to God.

Unfortunately, the expectation of the judicial institution as an extremely noble and authoritative institution began to be questioned by the public when watching a judicial drama that was too dramatized and full of fraudulent practices. Although supervision has been super tight both by state institutions and independent external institutions, in reality there are still many loopholes for sneaky and fraudulent practices. In addition, morality which is always shouted out loud by law enforcers actually turns into an empty song when it is in the courtroom. Morality is only used as a guise to infiltrate and at the same time as a justification for its decisions. Even,

The existence of mafia practices in justice institutions has actually been going on for a long time. In fact, criminologists have conducted research on irregularities in the world of justice. William J. Chamblis and Robert B. Seidman in his book entitled "Law, Order, and Power", wrote that the bend had begun in terms of the law, namely because of the existence of laws that reflected the interests of the ruling elite (the higher a group's) political and economic position). ${ }^{3}$ In fact both of them emphasize that irregularities in the world of justice occur because "judges must rely on their personal values when

1 Zaka Firma Aditya, "Penerapan Modal Sosial dalam Praktek Peradilan yang Berbasis kepekaan Sosial”, Legality Jurnal Ilmu Hukum, Vol. 25 No. 2, 2017, pp. 200-201.

2 Ibid., p. 201.

3 See, William J. Chambliss and Robert B. Seidman, Law, Order, and Power, Massachussett: Addison-Wesley, 1971. 
they make decisions in trouble cases". ${ }^{4}$ The other side that has the most potential to produce crime is the tendency and efforts of judges to gain wealth and power from their work.

The 2007 Global Corruption Report launched by Transparency International chose the theme Corruption in Judicial Systems. According to the report, corruption is seen as crippling the judicial system throughout the world and obstructing the human rights of fair and impartial justice. Huguette Labelle, chairman of Transparency International, stressed that with the corruption of the judiciary, those on the right side lose their hearing rights while the guilty are left untouched by the law. He further added that "money and political influence in the law break the social justice system: a system for the rich, on the other hand for the poor. If money and political influence are the basis of justice, those who are poor cannot compete ". ${ }^{5}$

Meanwhile, the report released by Tranparency International in the 2007 Global Corruption Report turned out to have an intervention in the conditions of justice in Indonesia where justice in Indonesia was still very corrupt. This is very relevant to the results of the Corruption Perception Index (IPK) of Indonesia in that year released by Transparency International of Indonesia (TII). In the survey of that year, there was a finding that vertical institutions (Police, Judiciary, Tax, BPN, Immigration, Customs \& Excise, Military and others) were still perceived to be very corrupt. Even more embarrassing, they are not awkward in asking for bribes, this is confirmed by reports of business actors that bribery initiatives are mostly carried out by the authorities. The court is reportedly the highest level of initiative to request bribes up to $100 \%$, followed by Customs and Excise 95\%, Immigration $90 \%$, BPN 84\%, Police 78\%, and Tax 76\%. Two categories of judicial corruption namely political interference and bribery are also very clearly visible. ${ }^{6}$

Even though the 2007 Global Corruption Report on Corruption in Judicial System was a report more than ten years ago, its condition is still very relevant to the current condition of Indonesian justice. Based on the latest data from Trasparency International of Indonesia (TII), Indonesia's ranking in 2019 was ranked 89 out of the 100 most corrupt in the world with a GPA of 40. Although it has increased its GPA by 2 (two) points from 2018, it has not been able to boosting the position of Indonesia as the most corrupt country in the world that is still ranked 85. In fact, the Corruption Perception

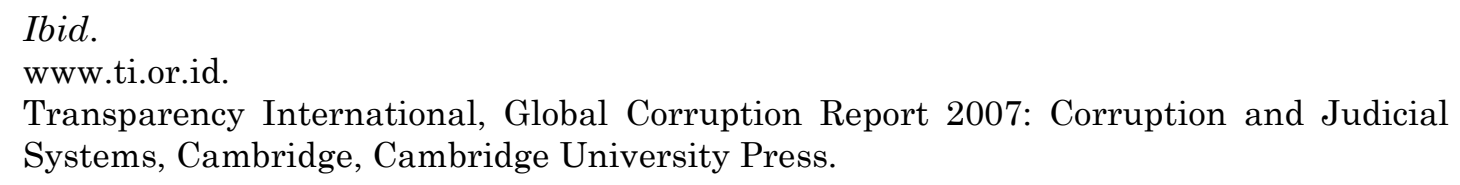


Index in Indonesia in the ASEAN region is only ranked 4 and far behind from neighboring countries such as Singapore (score 85), Brunei Darussalam (score 60) and Malaysia (score 53). Meanwhile, the institutions most affected by corruption cases are still dominated by legislative, judicial and police institutions. This is enough to show that the judiciary is still one of the most corrupt agencies in Indonesia.

Corruption in justice institutions is not new in recent years. the corruption case of the Corruption Court Judge and the Registrar of the Bengkulu District Court (PN) as revealed in the KPT OTT in September 2017 is one example of corrupt behavior in the judicial process in Indonesia. Not only in the PN environment, corruption cases are also found in the Religious Courts (PA). The case ensnared the Padang Panjang PA Judge in 2007 had just been decided by the Supreme Court (MA) with a sentence of 10 years in prison plus a fine of Rp. 200,000,000 subsidair 6 months in confinement in May 2017. The corruption case also ensnared the Constitutional Justice some time ago including a bribery case that ensnared the chairman of the Constitutional Court Akil Muchtar in 2014 and the Operation of Arresting (OTT) bribery case of the Constitutional Justice Patrialis Akbar in 2016. Worse, corruption was apparently not only done by judges within the judicial environment., but it is also a matter for clerks to do. In some cases, court clerks are liaisons between bribery and clients. In addition to the court clerk in Bengkulu District Court, several clerks were also caught in corruption cases, such as the clerk in the South Jakarta District Court, the Central Jakarta District Court, the North Jakarta District Court and the Registrar in the Medan Administrative Court. In some cases, court clerks are liaisons between bribery and clients. In addition to the court clerk in Bengkulu District Court, several clerks were also caught in corruption cases, such as the clerk in the South Jakarta District Court, Central Jakarta District Court, North Jakarta District Court and the Registrar in Medan Administrative Court. In some cases, court clerks are liaisons between bribery and clients. In addition to the court clerk in Bengkulu District Court, several clerks were also caught in corruption cases, such as the clerk in the South Jakarta District Court, Central Jakarta District Court, North Jakarta District Court and the Registrar in the Medan Administrative Court.

The above facts are sufficient to illustrate that corrupt behavior in the judiciary is so alarming. The KPK's action by eradicating corruption is deemed quite tactical and has the potential to save state money from corruptors. However, the KPK is still quite weak in terms of efforts to prevent corruption in Indonesia, including preventing corrupt behavior in the judicial environment. In fact, in the concept of legal protection, Philipus M. Hadjon 
(1987) describes "efforts to protect law as two inseparable parts, namely preventive or preventive measures and repressive measures or repression". ${ }^{7 T h e}$ disclosure of a new mode of corruption in the judicial process should be responded to in two ways, namely prevention and enforcement. Therefore, we need a strategy to prevent and eradicate corruption in Indonesia, especially in eradicating corrupt behavior in the judicial process.

The existence of corrupt behavior in the judiciary makes the judicial process that should be fast, simple and low-cost actually become not simple, protracted and costly. Therefore, in order to optimize efforts to realize the targets of justice reform, justice modernization is one of the vision formulated institutionally. Learning from the experiences of various successful countries in the judicial reform program, judicial modernization is believed to be the best method that must continue to be maximized. ${ }^{8}$ To realize this modernization, we need formulas that are expected to accelerate the implementation of the judicial modernization program. Among these formulations is through the supervision of litigation costs in court which are expected to be an alternative and preventive effort in eradicating corruptive behavior in the judicial process.

Most people and legal academics may have known and perfumed about the principle of Constante Justitie (fair trial) or commonly called quick, simple and low-cost justice. However, in practice the principle of justice is difficult to apply, which happens just the opposite where the judicial process is not simple and takes a long time and very large costs. Regarding the amount of costs incurred from the court process can not be released from the problem of corruption in the court.

\section{B. Method}

This research is a normative legal research. Legal research is prescriptive and applied, legal research is a process of finding legal rules, legal principles, and legal doctrines to address the legal issues at hand. This legal research is carried out to produce new arguments, theories or concepts as a prescription in solving the problem at hand. According to Peter Mahmud Marzuki, legal

\footnotetext{
7 See, Philipus M. Hadjon, Perlindungan Hukum Bagi Rakyat Indonesia: Sebuah Studi Tentang Prinsip-Prinsipnya, Penangannya Oleh Pengadilan Dalam Lingkungan Peradilan Umum Dan Pembentukan Peradilan Administrasi Negara, Jakarta, Bina Ilmu, 1987.

8 Salman, IESQ Based Court Modernization: Menuju Peradilan Modern Berbasis Kecerdasan Intelektual, Emosional, dan Spiritual, Cilegon, Pengadilan Agama Cilegon, 2009, p. 2.
} 
research is carried out to produce new arguments, theories or concepts as a prescription in solving the problem at hand. ${ }^{9}$

This study uses a statute approach and a conceptual approach. The statutory approach (statue approach) is carried out by examining all laws and regulations relating to the legal issues being addressed. Whereas the conceptual approach moves from the views and doctrines that develop in the science of law. By studying the views and doctrines in law, researchers will find ideas that give birth to legal notions, legal concepts, and legal principles that are relevant to the issue at hand.

\section{Result and Discussion \\ 1. Types of Corruption in Judicial Process}

Several research results have shown that the occurrence of judicial corruption practices has taken a long time to improve at every stage of the judicial process. Research conducted by Bappenas and the World Bank shows the existence of corrupt practices within the judiciary. Specifically, this report highlights the corrupt practices committed by the court clerks during the case registration. The research respondent stated that the registration fee that must be paid by justice seekers is quite expensive in excess of what should be paid according to applicable regulations. Starting from the research also revealed the practice of corruption for the parties when getting a copy of the decision. A copy of the decision which should be the right of the parties, however it turned out that it could only be obtained by the parties after being required to give an extra amount of money to the officials in court. Without more money, a copy of the decision will not be immediately handed over. ${ }^{10}$

Meanwhile, research conducted by Mardjono Reksodiputro ${ }^{11}$ also revealed the existence of judicial mafia practices. Even from this research can be mapped about the modes of corruption carried out by the police, prosecutors and judges in the Court. In the police institution, Mardjono quoted a term commonly developed in the community "reporting missing chickens, even goats missing". That is, if a crime victim reports to the police they will spend more money to share in operating costs from the police. In addition, the provision of more facilities to prisoners, especially those who are

9 See, Peter Mahmud Marzuki, Penelitian Hukum, Edisi Revisi, Jakarta, Kencana Predana Media Group, 2014.

10 Zakiya, W. et.al. Panduan Eksaminasi Publik, Jakarta, Indonesia Corruption Watch, 2003, p. 4.

11 See, Basyaib, et.al. Jakarta: Partnership for Governance Reform in Indonesia, Jakarta, Indonesia Corruption Watch, 2002. 
rich, accompanied by a certain amount of compensation has also long been the subject of gossip in the community.

While at the prosecutor's office, Mardjono revealed that in addition to extorting suspects, prosecutors can also release suspects on the grounds of lack of evidence. Playing with the indictment article, playing with the pros and cons of criminal charges is a fairly common mode of practice. Playing with the need to use authority to detain a suspect or defendant is also a case abuse of authority, both during the investigation stage in the police and prosecution in the prosecutor's office. These reasons should be supported by objective facts but have shifted to mere subjective considerations.

Mardjono also revealed corrupt practices in the court, especially regarding the verdict to be handed down, if in a civil case whether a lawsuit will be granted, a lawsuit is rejected, or a claim is declared unacceptable; in a criminal case whether the defendant will be found guilty and subject to punishment, and determine the level of sentence imposed; stated that the indictment of the public prosecutor was not proven by acquitting the defendant from all charges (vrijspraak); or stated release the defendant from all charges (ontslag van alle rechtsvervolging), as well as various other modes. This is very much influenced by the loose and elastic use of discretion by the judge by hiding behind the principle that the judge has the freedom to decide on a case submitted to him, trial facts. Use and application of the authority they have This is very open to the possibility of being misused in such a way as to cause judicial corruption. All of these will of course depend very much on how strong the ethics, integrity and commitment of law enforcement officials themselves. ${ }^{12}$

The same research was also conducted by the Indonesian Judicial Monitoring Society in 2017, where there were at least 21 (twenty one) modes of corruption that occurred during the judicial process, namely: ${ }^{13}$

Table 1. Modes of Corrupt Practices that Occur during the Trial Process

\begin{tabular}{cll}
\hline No & Corruption Mode & \multicolumn{1}{c}{ Information } \\
\hline 1 & Request for Service & $\begin{array}{l}\text { Advocates must prepare extra money } \\
\text { because the registration department in } \\
\text { Fees }\end{array}$ \\
\hline
\end{tabular}

12 Basuki Rekso Wibowo, Laporan Penelitian: Pembenahan Administrasi Peradilan, Jakarta, Pusat Penelitian dan Pembinaan Sistem Hukum Nasional Badan Pembinaan Hukum Nasional kemntrian Hukum dan Ham Republik Indonesia, 2012, pp. 8-9.

13 See, MaPPI FH UI, Modul Pemantauan Biaya Perkara Pengadilan Negeri di 5 Kota (Medan, Banten, Bandung, Yogyakarta, Malang), Jakarta, MaPPI FH UI and USAID, 2017, pp. 36-37. 


\begin{tabular}{|c|c|c|}
\hline & & $\begin{array}{l}\text { power of attorney from the defendant's } \\
\text { lawyer. Though the registration of the } \\
\text { power of attorney should be free, but if no } \\
\text { money is given, the registration process will } \\
\text { be delayed }\end{array}$ \\
\hline 2 & $\begin{array}{l}\text { Determination of the } \\
\text { Panel of Judges }\end{array}$ & $\begin{array}{l}\text { The choice of the Panel of Judges can be a } \\
\text { wide gap in corruption cases because in } \\
\text { some Courts, there are Panel of Judges who } \\
\text { are favored to handle cases. }\end{array}$ \\
\hline 3 & Decision Negotiations & $\begin{array}{l}\text { Before the decision was handed down, there } \\
\text { were many gaps in the case of corruption, } \\
\text { namely by negotiating the decision. Judges } \\
\text { who have been bribed are likely to give } \\
\text { verdicts on average } 2 / 3 \text { of the order. }\end{array}$ \\
\hline 4 & Marathon Trial & $\begin{array}{l}\text { To increase revenue, marathon trials are } \\
\text { usually carried out, which is a trial model } \\
\text { that is more than once a day }\end{array}$ \\
\hline 5 & $\begin{array}{l}\text { Illegal Levies for Case- } \\
\text { Free Certificate } \\
\text { (SKBP) or Certificate } \\
\text { Never Sentenced }\end{array}$ & $\begin{array}{l}\text { SKBP is a document that is needed by the } \\
\text { company or an individual to prove that they } \\
\text { have never been involved in a case or legal } \\
\text { case. The SKBP is much needed by the } \\
\text { Company, especially for IPO, mergers, } \\
\text { acquisitions and so on, so that usually the } \\
\text { Company will buy the SKBP even at a } \\
\text { quite expensive price. }\end{array}$ \\
\hline 6 & $\begin{array}{l}\text { Leges proof of } \\
\text { admission to court fees } \\
\text { or not }\end{array}$ & $\begin{array}{l}\text { Additional fees apply to ensure that the } \\
\text { case registration is actually registered or } \\
\text { entered }\end{array}$ \\
\hline 7 & $\begin{array}{l}\text { Claims, Appeals and } \\
\text { Appeals }\end{array}$ & $\begin{array}{l}\text { The amount of illegal fees exceeds the costs } \\
\text { that should be, so the difference in costs } \\
\text { beyond the official rate is certainly included } \\
\text { in the category of corruption }\end{array}$ \\
\hline 8 & Appeal and Cassation & $\begin{array}{l}\text { There are rates for speeding up the delivery } \\
\text { of an Appeal or Cassation file. In addition, } \\
\text { the usual mode of trading is buying and } \\
\text { selling information about the completeness } \\
\text { of the Appeal or Cassation file }\end{array}$ \\
\hline 9 & Decision Copy Fee & $\begin{array}{l}\text { To request a copy of the decision which } \\
\text { should be free, it is usually required a } \\
\text { relatively expensive fee for advocates. } \\
\text { However, in some cases, a copy of the } \\
\text { decision can be requested for free if the one } \\
\text { asking is LBH Probono's advocate }\end{array}$ \\
\hline 10 & $\begin{array}{l}\text { Cost of Power of } \\
\text { Attorney }\end{array}$ & $\begin{array}{l}\text { If the litigator uses an advocate, each } \\
\text { power of attorney is charged. Even though }\end{array}$ \\
\hline
\end{tabular}




\begin{tabular}{|c|c|c|}
\hline & & $\begin{array}{l}\text { the power of attorney that was registered } \\
\text { was free }\end{array}$ \\
\hline 11 & Summon for Witnesses & $\begin{array}{l}\text { There is a witness summons fee charged to } \\
\text { the parties. Whereas in civil cases, witness } \\
\text { summons has been included in the cost } \\
\text { component of litigation, while in criminal } \\
\text { cases there is no imposition of witness } \\
\text { summon costs }\end{array}$ \\
\hline 12 & Summon of the Parties & $\begin{array}{l}\text { There are costs for calling the parties, } \\
\text { which should have been included in the } \\
\text { officially regulated litigation component }\end{array}$ \\
\hline 13 & Notifications & $\begin{array}{l}\text { Sent to RW or Lurah or Village Head so } \\
\text { that information does not reach the parties }\end{array}$ \\
\hline 14 & $\begin{array}{l}\text { Notification and } \\
\text { Granting Access to } \\
\text { First Level Decisions, } \\
\text { Appeals, Judicial } \\
\text { Review of Decision }\end{array}$ & $\begin{array}{l}\text { The court clerk does not provide access for } \\
\text { the parties to be able to see or get a copy of } \\
\text { the decision. To get access to decisions, fees } \\
\text { are charged to the parties }\end{array}$ \\
\hline 15 & Confiscation & $\begin{array}{l}\text { To confiscate, some were immediately } \\
\text { executed but some were experiencing } \\
\text { delays. This is due to negotiations related } \\
\text { to confiscation fees and so on }\end{array}$ \\
\hline 16 & Session Schedule & $\begin{array}{l}\text { There are indications, to speed up the trial } \\
\text { schedule, an additional fee will be charged }\end{array}$ \\
\hline & Oaths & $\begin{array}{l}\text { Oaths will usually ask for money from the } \\
\text { parties after swearing witnesses }\end{array}$ \\
\hline 18 & Legal Aid & $\begin{array}{l}\text { Usually there is extortion of Posbakum } \\
\text { (Legal Aid Center) advocates to parties in } \\
\text { the name of an extension of the judges or } \\
\text { prosecutors }\end{array}$ \\
\hline 19 & $\begin{array}{l}\text { Case Remaining Loan } \\
\text { Money }\end{array}$ & $\begin{array}{l}\text { Usually there is money left over from the } \\
\text { court fee which is almost never returned to } \\
\text { the parties }\end{array}$ \\
\hline 20 & $\begin{array}{l}\text { Credit money by a } \\
\text { Substitute Registrar }\end{array}$ & $\begin{array}{l}\text { The parties usually give a credit to the } \\
\text { substitute registrar to facilitate } \\
\text { information relating to the case being } \\
\text { handled }\end{array}$ \\
\hline & Local inspection & $\begin{array}{l}\text { The judge asked for an allowance from the } \\
\text { parties }\end{array}$ \\
\hline
\end{tabular}

Meanwhile, the results of research conducted by Malang Corruption Watch in 2017 also showed a similar conclusion, that there are at least 6 (six) modes of corruption in the judicial process in Malang City Court. The mode of corruption includes the remaining costs of case management, registration of power of attorney, willingness of notification, copy of decision, local 
examination and execution fee. The number of modes of corruption in the judicial process is directly proportional to the number of corruption cases in the courts which reaches $33 \%$ at the national level. ${ }^{14}$

From some of the above studies it can be seen that the mode of corruption in the judiciary is basically almost the same even in different court locations. The usual mode of corruption starts from the case registration, examination of witnesses and experts, negotiation of the decision until after the decision to get a copy of the decision. Therefore, the disclosure of a number of corruption cases and patterns or modes of corruption in the judicial process should be a warning for law enforcers and the government to immediately parse existing cases and eradicate corrupt behavior in the judicial process.

\section{Litigation Cost Control Model in the Judicial Process}

According to Bambang Wijoyanto, one of the important principles in implementing good judicial management is the existence of a good supervision system that contains: details of important matters that need to be monitored to maintain the dignity and honor of the judicial authority, the existence of applicable codes of conduct and behavior, the availability of procedures and mechanisms of supervision that are intact and solid, the availability of people who has professionalism and integrity in conducting supervision. ${ }^{15}$ Therefore, as an effort to streamline the task of judicial oversight, the Supreme Court carries out the oversight task of the High Court. The task of oversight of the general court is carried out by the High Court of each District Court in its jurisdiction. The responsibility of the supervisory duty lies with the chair of the Court of Appeal.

The task of supervision is more of a non-technical oversight of the judiciary and concerns the personalities of the judges, because the supervision is part of the personal development of the judges. The oversight will greatly affect the promotion and transfer process of each judge in this case there is an irregularity in the judicial process that results in the birth of a controversial decision, then the panel of judges will be examined by a team led by the head of the Court of Appeal, with the assistant justices or directors at The Supreme Court relating to the type of case is a member of the

14 See, Malang Corruption Watch, Hasil Riset Pemataan Biaya Perkara di PN Kota Malang, Malang, Malang Corruption Watch, 2017.

15 Bambang Widjojanto, "Negara Hukum, Kekuasaan Kehakiman: Upaya Membangun Akuntabilitas Kekuasaan Kehakiman", Paper, presented on the Training of Human Rights for Indonesian Judicial Commission Network, Bandung, 30 June - 3 July 2010, p. 9. 
examination team. ${ }^{16}$ This monitoring system will be an effective repressive measure for judges who are judged to have violated the code of ethics and the code of conduct of judges. With the mechanism of the implementation of the supervisory authority, it will further emphasize the strategic role of the Supreme Court in the framework of providing legal and justice services for people searching for events in Indonesia.

In addition to the Supreme Court, another institution authorized to oversee the judicial process is the Judicial Commission. The Judicial Commission is given constitutional authority based on Article 24B of the 1945 Constitution to maintain and uphold the honor, dignity and conduct of judges. Beyond the Supreme Court and the Judicial Commission, there are also nongovernmental organizations and Non-Governmental Organizations (NGOs) that have the function of supervising the judicial process externally, some of them such as the Indonesian Judge Scout Society (MaPPI), ICW, the AntiCorruption Study Center (PUKAT), ELSAM, the Independent Judiciary Study and Advocacy Institute (LEIP), the Institute for Criminal Justice Reform (ICJR) and LBH-LBH, which are particularly pro-bono.

The public is quite well aware that the practice of corruption that has taken place in the judiciary has taken place starting from the first level of judicial institutions, the level of appeal, and even at the cassation level. The eradication of corrupt practices in justice institutions should ideally be done simultaneously and simultaneously at all levels of justice institutions. However, to do it must start from the body of the Supreme Court itself. According to Basuki Rekso Wiboro, to prevent the possibility of spoilage in judicial practice in general, efforts to reform and prevent immediate efforts must be made $\cdot{ }^{17}$ Corrections and changes towards achieving better goals, starting from the Supreme Court itself, so that later it is expected to be able to bring a multiplier effect on all levels of justice underneath. This includes cleaning up various judicial corruption practices.

As discussed earlier, the practice of judicial corruption usually begins from the case registration in court. Because, when litigating in court the first thing that advocates do is take care of the completeness of the administration of the trial, one of which is the registration of power of attorney to represent the litigants in court. Based on LBH Jakarta records (2012) ${ }^{18}$, for this stage

16 Asrun, A. M., Krisis Peradilan: Mahkamah Agung di Bawah Soeharto, Jakarta, ELSAM, 2004, p. 127.

17 Basuki Rekso Wibowo, Op.Cit., p. 12.

18 Ahmad Biky, "Gerakan Advokat Anti Korupsi dalam Pemberantasan Korupsi Peradilan", Online LBH Jakarta, 2014, retrieved from https://www.bantuanhukum.or.id/web/gerakan-advokat-anti-korupsi-dalampemberantasan-korupsi-peradilan 
of the process alone five District Courts in DKI Jakarta apply the same and uniform unofficial tariffs in the range of $\mathrm{Rp}$. 100,000.00 (one hundred thousand rupiahs) whereas if referring to the Government Regulation of the Republic of Indonesia Number 53 Year 2008 Concerning the Types and Rates of Non-Tax State Revenues Applicable to the Supreme Court and the Judicial Bodies Subordinate, the registration of the power of attorney to represent the litigants in court only Rp. 5,000 (five thousand rupiah).

In fact, one important pillar in the implementation of good governance (Good Governance) is the existence of a justice system that is free from executive interference, is not corrupt and professional. One aspect that requires attention in the context of supervision of the judiciary is by applying the principles of transparency and ease in accessing information. Transparency of the decision according to Y. Sogar Simamora is clearly not a prohibition even from the perspective of legal reform in order to increase the authority of the judiciary, this is very important because the easier access to information (decisions) the better the community will control. ${ }^{19}$ Furthermore, no less important is the urgency of the decision as a reference for the community including law enforcement, regarding the development of a new rule of law to solve a legal problem, and academic interests both for legal research, legal journals and drafting of laws.

In the Supreme Court's 2010-2035 Blueprint, the Supreme Court actually has a commitment towards modern justice. One of them is by changing the litigation fee system in cash to non-cash through banks. In accordance with the Supreme Court Circular Letter (SEMA) Number 04 of 2008 concerning Collection of Litigation Fees, where the payment of civil, religious civil and State Administration cases must be paid by the litigants through banks. Therefore, it should no longer be justified if there are employees receiving litigation fees directly from the litigants. But unfortunately, this SEMA has no sanctions if there are employees who receive litigation fees directly / in cash. Coupled with the lack of supervision,

The judiciary, with advances in information and technology systems, should have been able to put in place a model of supervision through an online whistleblowing system, although this idea is currently being developed. This Whistleblowing can be used as an alternative for processing complaints, complaints and providing information about KKN indications conducted by individuals within the judiciary. Some institutions that have implemented this whistleblowing system have proven to be effective in suppressing the level of KKN in their institutions such as the KPK, the Constitutional Court

19 See, Y. Sogar Simamora. Hukum Kontrak (Kontrak Pengadaan Barang dan Jasa Pemerintah di Indonesia), Surabaya, Kantor Hukum “Wins \& Partners”, 2013. 
(MK) and other ministries. With the whistleblowing system, justice seekers can complain about their irregularities starting from the determination of the cost of litigation registration, trial process to post decision. In this way, Supreme Court supervisory bodies can immediately follow up complaints and allegations of KKN practices carried out by individuals in the judiciary. But what is the focus in the whistleblowing system is the identity of the information provider who must be professionally kept confidential.

The application of the whistleblowing complaint system must also be balanced with the modernization of case management. In recent years, The Supreme Court has succeeded in modernizing the case management by integrating information technology in providing information desks as one of the strategies to erode the pile of cases. This service is based on online information technology so that it can be accessed anywhere and anytime. The provision of information desks in each court has had a positive impact on several matters, including:

1) Minimize the opportunity for litigants to meet with judges and clerks

2) Make it easy for litigants and court users to find and obtain copies of decisions

3) Pressing costs because the Supreme Court's website can be accessed from anywhere.

Through this feature, the court of first instance can conduct data communication with the Supreme Court of Indonesia in two directions for sending electronic documents for cassation and reconsideration efforts so as to minimize litigation costs. For the Supreme Court of the Republic of Indonesia, if the court uses this feature it will immediately provide information in real time regarding cases that will be submitted for legal action. Not only that, the Indonesian Supreme Court can directly download the included files as SEMA 14/2010. All activities carried out by the Supreme Court of the Republic of Indonesia, from opening, downloading, registering, to uploading decisions, will be automatically communicated automatically through the interface system for the filing court. For the people,

In addition, data communication must also be carried out through the system to the registered court filing electronic mail. In addition to judicial remedies and a review of the function of this feature, it should be able to be used by the courts of first instance and appeals when an appeal is filed. In addition to the progress in disclosure of information in the form of publication of decisions in terms of improving accountable administration of justice, the Supreme Court as a judicial body in charge of four judicial environments has issued Circular Letter No. 04 of 2012 concerning Recording Processes The judge. This SEMA was published to ensure the implementation of the trial 
which was more transparent, accountable and orderly, so in addition to the record of the substitute registrar set forth in the minutes of the trial which had been regulated in article 202 paragraph (1) of the Criminal Procedure Code, audio-visual recording was needed in a systematic, orderly and inseparable manner. from the permanent procedure of the trial. The recording of this trial should be appreciated because it can maximize the performance of the judiciary and minimize the negligence of court officials and as a form of public transparency.

\section{Conclusion}

The practice of judicial corruption has been going on for a long time and until now it can still be found in judicial institutions in Indonesia. Even, the practice of judicial corruption is a problem that has been known by the public. It is common knowledge that any civil or criminal case can basically be regulated by the order starting from the level of investigation, investigation, prosecution to review in the Supreme Court. Generally, the community will consider that one of the causes of corruption in court institutions is due to their low salaries, collusive recruitment and career systems, weak internal and external supervision systems, and sanctions that do not work functionally and sustainably, low ethics and integrity law enforcement apparatuses, and are increasingly made worse by a non-transparent court administration system. From this explanation, two conclusions can be drawn, namely:

1) There are at least 21 modes used by individuals in the judiciary, from registration to post-ruling registration, including:demand for fees, determination of judges, negotiation of decisions, marathon trials to increase revenue, marathon trials are usually carried out, namely a trial model that is more than once a day, illegal levies for case-free statements (SKBP) or certificates never been sentenced, proof of admission to court fees or not, rates to expedite appeals and cassation, costs of copy of decisions, costs of power of attorney, costs of summoning witnesses, summons of parties, willingness of notification, notification and granting access to first-rate decisions, appeals, cassation and PK, determination confiscation, trial schedule, oath money by oath clerk, Bakum post, rest of the case down payment, credit by substitute registrar and local examination where the judge asks for an allowance from the parties.

2) To overcome and reduce the practice of judicial corruption requires commitment from the judiciary. One way is to maximize the use of technology and information, namely through online whistleblowing complaints to monitor litigation costs. So that later, justice seekers can 
report and complain if there are indications of corrupt practices during the trial process. Complaints must be followed up immediately by an internal regulatory body. However, the application of the whistleblowing complaint system must also be balanced with the modernization of litigant management. In recent years, The Supreme Court has succeeded in modernizing the case management by integrating information technology in providing an integrated information desk as one of the strategies to erode the pile of cases. This service is based on online information technology so that it can be accessed anywhere and anytime.

\section{E. Acknowledgment}

The Authors would like to thank profusely to the editor of the Indonesian Journal of Advocacy and Legal Services, Faculty of Law Universitas Negeri Semarang. In addition, The Authors also thank to Center for Research and Case Analysis of Indonesian Constitutional Court and Faculty of Law Universitas Muhammadiyah Malang.

\section{F. Declaration of Conflict of Interest}

The authors state that there is no potential conflict of interest in the research, authorship, and/or publication of this article.

\section{G. Funding}

The authors do not obtain financial support from any party for research, authorship, and/or publication of this article.

\section{H. References}

Aditya, Z. F. (2017). Penerapan Modal Sosial dalam Praktek Peradilan yang Berbasis kepekaan Sosial. Legality Jurnal Ilmu Hukum, 25(2), 200219.

Asrun, A. M. (2004). Krisis Peradilan: Mahkamah Agung di Bawah Soeharto. Jakarta: ELSAM.

Basyaib, et.al. (2002). Jakarta: Partnership for Governance Reform in Indonesia. Jakarta: Indonesia Corruption Watch.

Biky, A. (2014). "Gerakan Advokat Anti Korupsi Dalam Pemberantasan Korupsi Peradilan", Online LBH Jakarta, retrieved from https://www.bantuanhukum.or.id/web/gerakan-advokat-antikorupsi-dalam-pemberantasan-korupsi-peradilan/ 
Chambliss, W. J., \& Seidman, R. B. (1971). Law, Order, and Power. Massachussett: Addison-Wesley.

Hadjon, P. M. (1987). Perlindungan Hukum Bagi Rakyat Indonesia: Sebuah Studi Tentang Prinsip-Prinsipnya, Penangannya oleh Pengadilan dalam Lingkungan Peradilan Umum dan Pembentukan Peradilan Administrasi Negara. Jakarta: Bina Ilmu.

Malang Corruption Watch. (2017). Hasil Riset Pemetaan Biaya Perkara di PN Kota Malang. Malang: Malang Corruption Watch.

MaPPI FH UI. (2017). Modul Pemantauan Biaya Perkara Pengadilan Negeri di 5 Kota (Medan, Banten, Bandung, Yogyakarta, Malang). Jakarta: MaPPI FH UI and USAID.

Marzuki, P. M. (2014). Penelitian Hukum. Jakarta: Kencana Predana Media Group.

Salman, S. (2009). IESQ Based Court Modernization: Menuju Peradilan Modern Berbasis Kecerdasan Intelektual, Emosional, dan Spiritual. Cilegon: Pengadilan Agama Cilegon.

Simamora, Y. S. (2013). Hukum Kontrak (Kontrak Pengadaan Barang dan Jasa Pemerintah di Indonesia). Surabaya: Kantor Hukum "Wins \& Partners".

Transparency International. (2007). Global Corruption Report 2007: Corruption and Judicial Systems. Cambridge: Cambridge University Press.

Transparency International Indonesia, www.ti.or.id.

Wibowo, B. R. (2012). Laporan Penelitian: Pembenahan Administrasi Peradilan. Jakarta: Pusat Penelitian dan Pembinaan Sistem Hukum Nasional Badan Pembinaan Hukum Nasional kemntrian Hukum dan HAM Republik Indonesia.

Widjojanto, B. (2010). "Negara Hukum, Kekuasaan Kehakiman: Upaya Membangun Akuntabilitas Kekuasaan Kehakiman", Paper, presented on the Training of Human Rights for Indonesian Judicial Commission Network, Bandung, 30 June - 3 July 2010.

Zakiya, W. et.al. (2003). Panduan Eksaminasi Publik. Jakarta: Indonesia Corruption Watch. 